\title{
Measuring the Importance of Non-Technical Skills for Integration into Metalwork Technology Curriculum Using Structural Equation Modelling
}

\author{
Bakare Shola Francis
}

Adekunle Ajasin University, Nigeria, shola.bakare@aaua.edu.ng

\author{
Azlan Abdul Latib \\ Assoc. Prof., Universiti Teknologi Malaysia, Malaysia, p-azlan@utm.my \\ Evarina Amiron \\ Mrs., Universiti Teknologi Malaysia, Malaysia, evarinaamiron@ gmail.com \\ Kamalularifin Subari \\ Dr., Universiti Teknologi Malaysia, Malaysia, p-arifin@utm.my \\ Yusri Kamin \\ Assoc. Prof., Universiti Teknologi Malaysia, Malaysia, p-yusri@utm.my
}

This study aims to measure the significance of non-technical skills for integrating into metalwork technology curriculum of technical colleges in Nigeria. The data collected through questionnaire survey consisted of 283 responses. The findings revealed that the mean values for all identified components of non-technical skills indicated their importance and suitability for integration into the curriculum. The study developed models using structural equation modelling (SEM) technique. The results from SEM indicated that the correlation matrix, factor loadings, composite reliability, and average variance extracted for the measurement and structural models were all confirmed fit and suitable. The study also revealed that the relationship among the components that made up of the structural model were statistically significant. Communication skills was ranked the highest among the eight components that were considered important while problem-solving skills were ranked the lowest. In order to achieve the integration, suggestions are made relating to policy structure for the development of non-technical skills in Nigeria technical colleges.

Keywords: measuring, non-technical skills, integration, metalwork technology, curriculum

Citation: Francis, B. S., Latib, A. A., Amiron, E., Subari, K., \& Kamin, Y. (2020). Measuring the Importance of Non-Technical Skills for Integration into Metalwork Technology Curriculum Using Structural Equation Modelling. International Journal of Instruction, 13(3), 317-328. https://doi.org/10.29333/iji.2020.13322a 


\section{INTRODUCTION}

In the world over, non-technical skill (NTS) has gradually gained a wide recognition and considered as critical for recruitment in today's workplace. The past study indicated that employers of labour would rather opt for employees with NTS such as communication skill, teamwork skill, lifelong learning skill, and self-management skill, critical thinking skill, problem-solving skill, and others in addition to job-related skills (Akinyemi, Ofem, and Ikuenomore, 2012). In Nigeria, metalwork industries are recognised for the provision of daily essential needs and is another prominent area where unemployment is attacking hard in the nation. This may be in connection with metalwork technology graduates lacking the important NTS that could enhance their employability. Despite the acquisition of professional or practical skills, most graduates lack NTS that can make them easily access employment. This implies that there is a mismatch between the skills acquired by graduates and those required by employers (Lindsay, 2002; Pitan Oluyomi and Adedeji, 2012; Teijeiro, Rungo, and Freire, 2013). Unemployment growth in Nigeria is still on the increase or high rate (Chijioke, 2016; Salami, 2013) The universal rating by International Labour Organisation (ILO, 2017) indicated that unemployment is the prime menace to social stability in many countries (including Nigeria).

In spite of successfully finishing advanced education, there are still several young people who lack basic skills required to back their post-school life or who are now being considered as 'unemployable'. For them to be employable or suitable for the employment market in Nigeria, they need additional skills (Oduwole, 2015). The graduates as potential employees, regardless their field of study are greatly expected to have the right kind and aggregate of NTS and talents which are greatly required by employers for endless development and achievement in workplaces (Abas-Mastura, Imam, and Osman,2013).

The research problem, therefore, is that NTS has not been given necessary attention in the field of metalwork technology with a link to the technical skills as demanded in the industries, which has steered towards unemployment among the metalwork technology graduates. It was indicated that TVET programme curriculum in Nigeria pays less attention to NTS development and graduates are not trained with NTS required by industries (Ismail and Mohammad (2015)). Deba Jabor, Buntat, and Musta'mal (2014) noted that placing emphasis on technical skills alone and ignoring other skills (such as non-technical skills) that could assist the technical college graduates to be employable seems to be rampant among the developing nations like Nigeria.

In view of this, the study is considered essential since there is difference in culture, management, and policy in the educational system. However, researchers and policy makers have not arrived at a compromise on the non-technical skills that actually needed to be integrated into metalwork technology curriculum in Nigeria technical colleges. The study, therefore, aimed at determining the important components of non-technical skills that need to be integrated into metalwork technology curriculum in Nigeria technical colleges. Consequently, the study developed models (measurement and structural models) using structural equation modelling (SEM) technique for determining the important components of non-technical skills that suitable for integrating into 
metalwork technology curriculum of technical colleges in Nigeria. The main research aims at determining the important components of non-technical skills that can be integrated into metalwork technology curriculum in Nigeria technical colleges. Specifically, the research sought to: (i) determine the important components of nontechnical skills that need to be integrated into metalwork technology curriculum in technical colleges. (ii) examine the relationship among the components of non-technical skills that make up the structural model and curriculum integration.

\section{METHOD}

Data for the study were obtained through primary (questionnaire) and secondary (literature) approaches. The study involved data collection with the use of structured questionnaire. Three hundred and twenty five (325) sets of questionnaire containing 59 items were produced and administered, out of which Two Hundred and eighty three (283) were considered usable for the analysis after data screening. The respondents which consist of 242 industry professionals and 41 metalwork technology teachers in technical colleges. The instruments was validated by five (5) experts from University of Lagos (UNILAG), Lagos state, Nigeria. The study was carried out between $27^{\text {th }}$ of February to $2^{\text {nd }}$ of April 2019 in Ogun, Ondo, and Osun states of south western part of Nigeria. Available data were analysed through statistical methods such as mean, standard deviation, ranking, and SEM. Structural equation modelling (SEM) is an innovative statistical method that can be used for analysing data (Awang, 2015). Similarly, SEM is used to determine the fitness of measurement model for latent variables which could be run with slight effort. It makes use of mixture of quantitative data and the causal or correlational assumptions into the model. SEM can be used to measure the validity of constructs and support the research with the development of fit indices (Tabachnick, Fidell, and Ullman, 2007).

\section{Data Analysis}

Table 1 shows the mean value, standard deviation (SD), and rank for the components of non-technical skills considered for integrating into metalwork technology curriculum. As appeared in the Table, the study revealed that the respondents opinion reflected the highest ranked mean for communication skills (4.38), to be followed in sequence order of mean values for creative thinking skills (4.35), interpersonal skills (4.340, learning skills (4.24), self-management skills (4.08), decision making skills (3.72), teamwork skills (3.59), and problem solving skills with the lowest mean value of (3.43). The overall mean value for the entire components stood at (4.02) which indicated that they are very important respectively. 
Table 1

Ranking of Important Components of Non-Technical Skill for Integration

\begin{tabular}{llllll}
\hline Code & Components & Mean & SD & Rank & Status \\
\hline COS & Communication skills & 4.38 & .727 & 1 & Very important \\
\hline CTS & Creative thinking skills & 4.35 & .668 & 2 & Very important \\
\hline IPS & Interpersonal skills & 4.34 & .685 & 3 & Very important \\
\hline LES & Learning skills & 4.24 & .723 & 4 & Very important \\
\hline SMS & Self-Management skills & 4.08 & .767 & 5 & Very important \\
\hline DMS & Decision making skills & 3.72 & .760 & 6 & Very important \\
\hline TES & Teamwork skills & 3.59 & .772 & 7 & Very important \\
\hline PSS & Problem solving skills & 3.43 & .951 & 8 & Important \\
\hline Total & & 4.02 & .757 & & Very Important \\
\hline
\end{tabular}

\section{Measurement Model}

In order to analyse data through AMOS, there are two most important steps required (Awang, 2014). These are measurement and structural models. Awang (2014) though, referred to measurement model as discriminant validity, usually implies validity of construct. To achieve discriminant validity of constructs, it means all the redundant items in a construct are deleted while the remaining items correlate strongly with the construct. Likewise, measurement model captures some important components of goodness-of-fitness model requirement. The values obtained for the initial model as shown in Figure 1 are: Chi-Square $=1968.507, \mathrm{DF}=870$, Ratio=2.263, $\mathrm{P}=.000, \mathrm{CFI}$ $=.871, \mathrm{IFI}=.872, \mathrm{TLI}=.860, \mathrm{RMSEA}=.067 . \mathrm{It}$ was however found that the model did not meet the requirements for goodness of fit. In order to achieve the goodness of model fit, after going through the modification indices, it was found that the model could be modified further through trimming. Therefore, trimming of the model in Figure 2 was carried out and the values attained are: Chi-Square $=1191.903, \mathrm{DF}=636$, Ratio $=1.874$, $\mathrm{P}=.000, \mathrm{CFI}=.910, \mathrm{IFI}=.911, \mathrm{TLI}=.900, \mathrm{RMSEA}=.056$. The measurement model estimated for the determination of confirmatory factor analysis (CFA) with the primary objective of confirming the model fit and validity. As presented in Figure 2, it was established that the goodness of fit is in agreement with the laid down principles (Awang, 2014). 


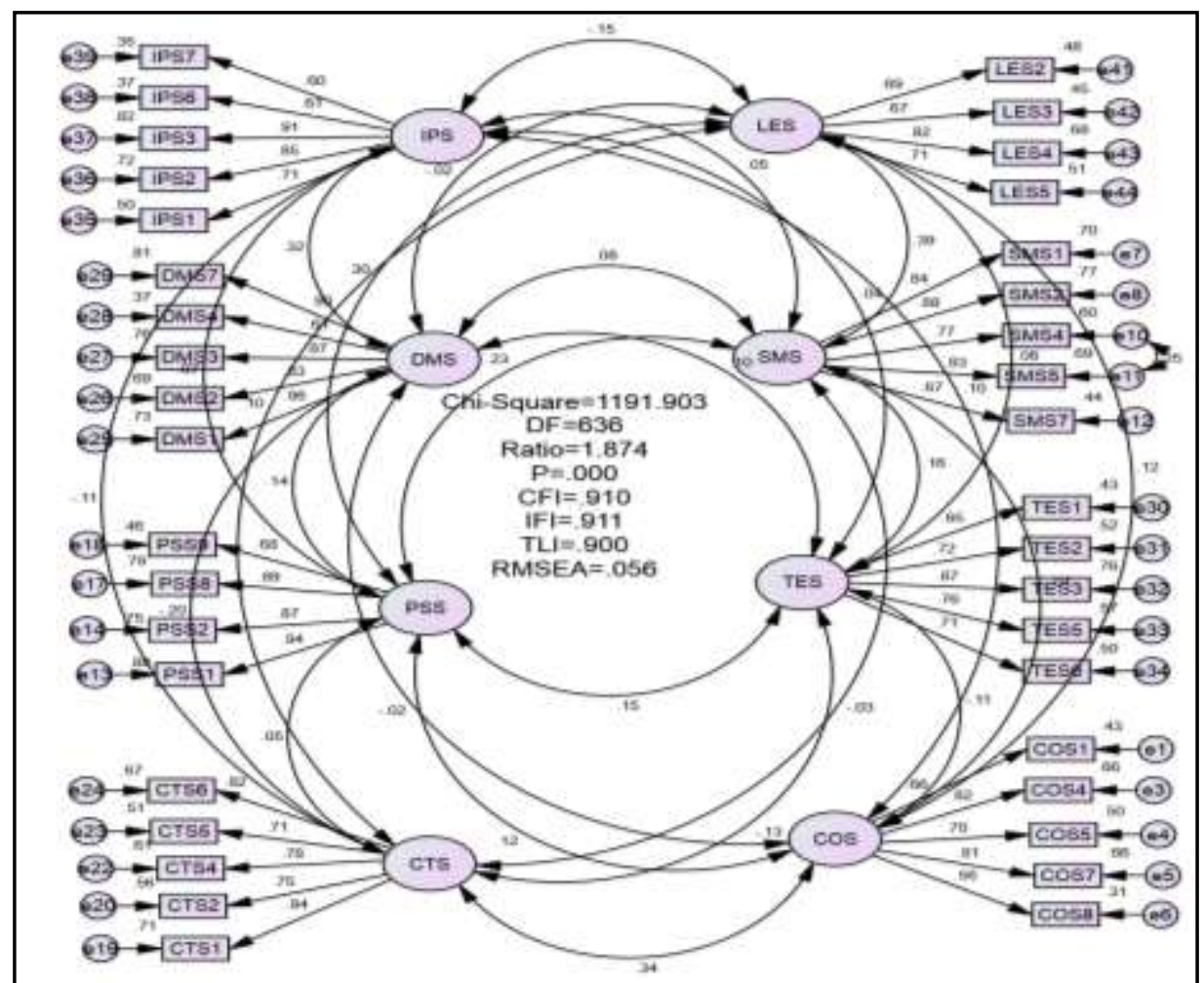

Figure 1

Revised Measurement Model of the Constructs for Integrating Non-Technical Skills into Metalwork Technology Curriculum

Table 2 illustrates the values of the average variance extracted (AVE) as appeared in the diagonal form across the table while the correlation between the constructs are the values in the cells underneath. In order to attain discriminant validity, the highlighted values in the diagonal axis should be higher in value than those in column and rows.

Table 2

Correlation Matrix for the Research Constructs

\begin{tabular}{lllllllll}
\hline & IPS & LES & DMS & SMS & PSS & TES & CTS & COS \\
\hline IPS & 0.74 & & & & & & & \\
\hline LES & 0.15 & 0.72 & & & & & & \\
\hline DMS & 0.32 & 0.03 & 0.81 & & & & & \\
\hline SMS & 0.06 & 0.30 & 0.08 & 0.80 & & & & \\
\hline PSS & 0.07 & 0.30 & 0.14 & 0.23 & 0.84 & & & \\
\hline TES & 0.04 & 0.06 & 0.03 & 0.16 & 0.15 & 0.74 & & \\
\hline CTS & 0.11 & 0.10 & 0.20 & 0.03 & 0.05 & 0.13 & 0.78 & \\
\hline COS & 0.10 & 0.12 & 0.02 & 0.01 & 0.12 & 0.11 & 0.34 & 0.71 \\
\hline
\end{tabular}




\section{Structural Model}

The structural model was purposely developed to bring all the constructs together into a single structural equation model using Analysis of Moment Structure (AMOS). The constructs are brought together to show the relationship between constructs in conformity with the hypothesis earlier set for the study. Composite or full structural model is when both models are combined (Weston and Gore Jr, 2006). The CFA is being represented by measurement models which normally show how the variables are interpreted by the items indicators. The structural equation model is a comprehensive and flexible analytical technique being applied in complex multivariable research models by using the combination of factor analysis and multiple regression as well as path analysis (Kline, 2015). It helps to clearly and explicitly state the pattern of relationship between variables, either latent or observed variables. It also makes possible the prediction concerning the direction among the set of variables and modelling of indirect effect. According to (Weston and Gore Jr, 2006), SEM statistical analysis are covariance-based which can be in operational through AMOS, EQS, and LISREL. In order to validate model for a latent construct, the technique must consider unidimensionality, validity, and reliability of the latent construct. These series of process will be taken into consideration prior to modelling their interrelationship in a structural equation modelling (SEM). After attaining reliability and validity of the constructs, the initial structural model presented in Figure 2. has the following modification indices; Chi-Square $=1372.190, \mathrm{DF}=662$, Ratio $=2.073, \mathrm{P}=.000, \mathrm{CFI}=.885, \mathrm{IFI}=.886$, TLI .878 , and RMSEA $=.062$.

Figure 2 shows the revised structural model. In accordance with the requirements of SEM/AMOS, the model was modified to improve the modification indices. After necessary modification, the values obtained are follows; Chi-Square $=990.966$, DF $=524$, Ratio $=1.891, \mathrm{P}=.000, \mathrm{CFI}=.909, \mathrm{IFI}=.910, \mathrm{TLI}=.903$, and $\mathrm{RMSEA}=.056$ 


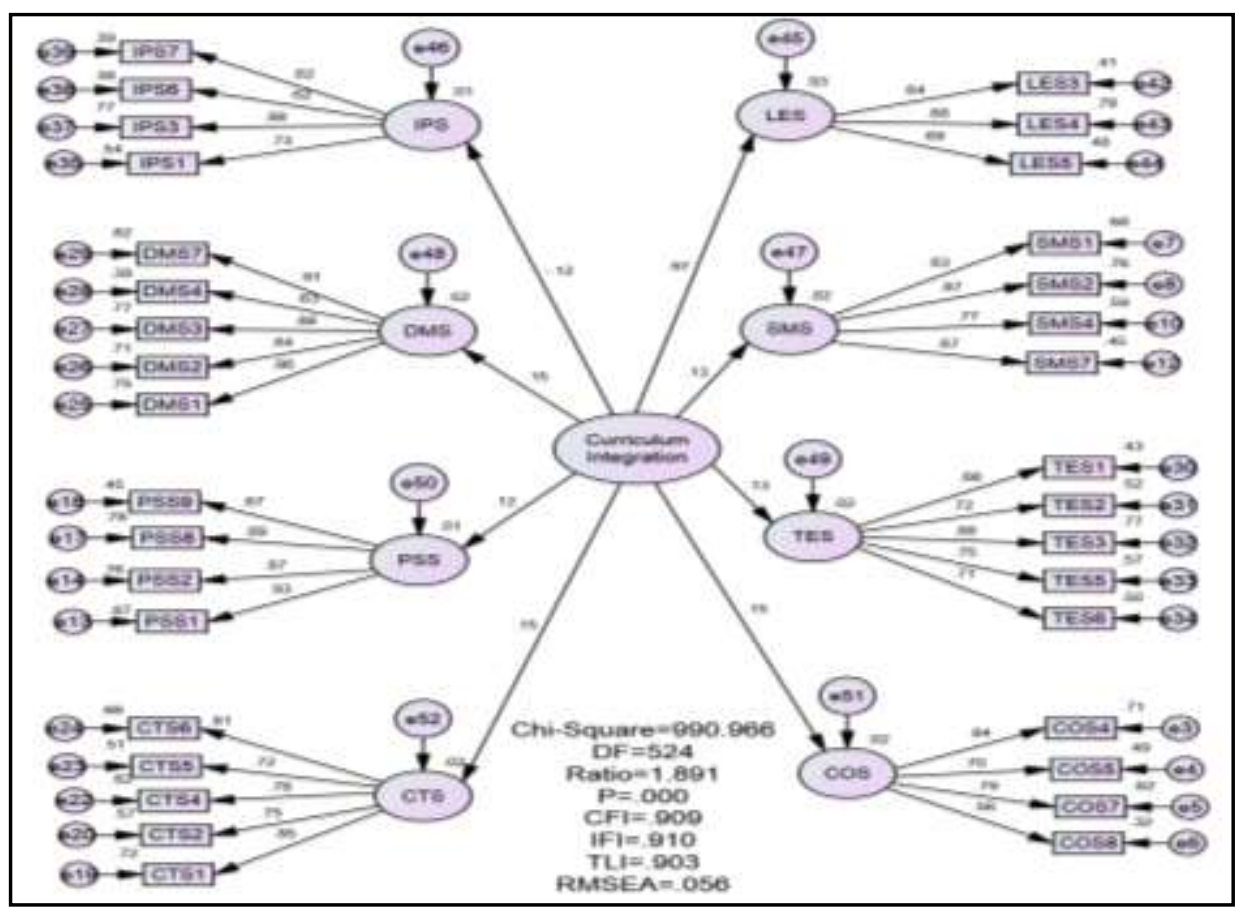

Figure 2

Revised Structural Model for Integrating Non-Technical Skills into Metalwork Technology Curriculum

Table 3

Standardized Regression Weight and Its Significance for the Entire Path in the Model

\begin{tabular}{llllllll}
\hline Construct & Path & Variable & Std. Estimate & S.E & CR & P-Value & Result \\
\hline LES & $<---$ & $\begin{array}{l}\text { Curriculum } \\
\text { Integration }\end{array}$ & .966 & 1.14 & 3.26 & .001 & Significant \\
\hline IPS & $<---$ & $\begin{array}{l}\text { Curriculum } \\
\text { Integration }\end{array}$ & -.121 & 056 & -1.91 & .049 & Significant \\
\hline SMS & $<---$ & $\begin{array}{l}\text { Curriculum } \\
\text { Integration }\end{array}$ & .126 & .065 & 11.43 & $* * *$ & Significant \\
\hline DMS & $<---$ & $\begin{array}{l}\text { Curriculum } \\
\text { Integration }\end{array}$ & .152 & .063 & 12.90 & $* * *$ & Significant \\
\hline TES & $<---$ & $\begin{array}{l}\text { Curriculum } \\
\text { Integration }\end{array}$ & .127 & .075 & 9.26 & $* * *$ & Significant \\
\hline PSS & $<---$ & $\begin{array}{l}\text { Curriculum } \\
\text { Integration }\end{array}$ & .115 & .063 & 15.53 & $* * *$ & Significant \\
\hline COS & $<---$ & $\begin{array}{l}\text { Curriculum } \\
\text { Integration }\end{array}$ & .150 & .072 & 1.91 & .038 & Significant \\
\hline CTS & $<---$ & $\begin{array}{l}\text { Curriculum } \\
\text { Integration }\end{array}$ & .154 & .059 & 14.56 & $* * *$ & Significant \\
\hline
\end{tabular}

*** Indicate in the table highly significant, $\mathrm{p}$-value is less than $0.001(\mathrm{p}$-value $<0.001)$ 


\section{FINDINGS AND DISCUSSION}

Based on the respondents' responses, analysis revealed that the mean value of the nontechnical skills in the order of ranking to be: communication skills, creative thinking skills, interpersonal skills, learning skills, self-management skills, decision making skills, teamwork skills, and problem solving skills. The analysis also shows the measurement model using SEM for the 8 (eight) constructs and were all confirmed fit after necessary modification. The analysis shows the correlation matrix, factor loadings, composite reliability, and average variance extracted for the measurement model and were all confirmed suitable. After the confirmation of the measurement model, the analysis shows the structural model which was validated with SEM and confirmed to be fit and valid. The study tested only one alternative hypothesis showed the existence of relationship between all the constructs that made up of the structural models and curriculum integration, which comprise of self-management skills (SMS), teamwork skills (TES), communication skills (COS), interpersonal skills (IPS), decision making skills (DMS), problem solving skills (PSS), creative thinking skills (CTS), and learning skills (LES). Consequently, based on the results shown in Table 5, the paths of hypothesis in this research indicated that there is a significant relationship among the constructs and curriculum integration. The results of this study revealed relationship among the above stated constructs and a strong support for the hypothesis as established in the final structural model in Figure 4. Therefore, the hypothesis is accepted and empirically supported by this research. By implication, the research finding shows that the non-technical skills have relevant in the curriculum integration as demonstrated in the final structural measurement model. This research finding is consistent with the empirical findings by Yost and Tucker (2000) who endorse a strong relationship between successful teamwork and emotional intelligence.

In this study, the mean value of non-technical skills components were ranked in order of highest to the lowest mean value as presented accordingly in table 1 . The rating in chronological sequence of $1^{\text {th }}, 2^{\text {nd }}, 3^{\text {rd }}, 4^{\text {th }}, 5^{\text {th }}, 6^{\text {th }}, 7^{\text {th }}$ and $8^{\text {th }}$ indicates an important as positioned by respondents on the components of non-technical skills. These are: communication skills, creative thinking skills, interpersonal skills, learning skills, selfmanagement skills, decision making skills, teamwork skills, and problem-solving skills which showed that the 8 (eight) skills were rated to be important for integration into metalwork curriculum.

This study found communication skills to be the highest rated skills which indicated that it is very important for integrating into metalwork technology curriculum. This also implies that the possession of communication skills will go a long way to assist the students after graduation to be found worthy for employment. This study is in congruent with the outcome of the previous scholars' researches who found oral and written communication as essential skills that are highly demanded by employers of labour for the absorption of prospective employees into the workplace. (Akinyemi et al., 2012b; Buntat et al., 2013; Laguador and Dotong, 2013; Leveson, 2000). Creative thinking is another skills revealed in this study as important to be possessed by metalwork technology students. In line with the available literature, creative thinking skills is seen 
as the quality of an individual to reason innovatively (Heimler, 2010). Interpersonal skills are found in this study to be important and relevant for integrating into the curriculum of students in the field of metalwork technology. The findings established that the development of interpersonal skills will assists in closing the gap between the skills acquired by graduates and those that are required by employers (Inti et al., 2015; Rasul and Mansor, 2013; Shafie and Nayan, 2010).

As part of the findings of this study, learning skills are found to be important and expected to be possessed by students of metalwork technology in technical colleges in order for them to be relevant in the world of work. In line with this study, Blom and Saeki (2011) submitted that employers expected graduates to possess the ability of learning together with their professional skills so as to be qualified for employment. The current study found self-management skills as one of the skills that needed by metalwork technology graduates from Nigeria technical colleges. This study showed that selfmanagement skills are relevant and important to be considered for integrating into the curriculum. In support of this research findings, Shafie and Nayan (2010) gave an account of some constituents of self-management skills such as honesty, integrity, confidence, self-control, personal grooming, and understanding as those qualities being demanded from prospective employees by the employers of labour. To corroborate the support for this study, Shafie and Nayan (2010) reported that self-management skills was rank $3^{\text {rd }}$ among the important skills that employers required from graduates. The findings of this study have revealed that decision making skills is another skills that is considered to be important for metalwork technology students to acquire.

Buntat et al. (2013) found that decision making is one of the essential skills demanded by employers in the industries. Also, in agreement with this study Holdsworth and Gearhart (2002) found that decision making is important and apply to all industries regardless of the field of study. The authors were of the opinion that laying importance on the possession of job-related skills only can render students to be redundant. AbasMastura et al., (2013) referred to decision making skills as judgment skills in their study, in which they emphatically stated that such skill is very much desired by employers in any organization. Chithra (2013) recommended that curriculum should be updated at reasonable and regular interval to cater for the requirement of the industry. The findings of this research revealed that teamwork skills are important to metalwork technology students and thereby good for integrating into the curriculum. Teamwork is otherwise known as working cooperatively. This findings is in line with the submission of Buntat (2004) that teamwork assisted employees to speed up their productivity which in turn saves time. In the same vein, Tabatabaei and Lam (2013) reported that teamwork is important in engineering workplace and their curriculum. Norani (2006) also laid emphasis on the relevance of working cooperatively in the workplace. Similarly, DupinBryant (2008) opined that business world cannot co-exist in the absence of group which implies that teamwork is important and required to be possessed by prospective workers. To execute any particular job in the workplace where workers are in large numbers, there is tendency for them to require the assistance of each other to get the work done.

International Journal of Instruction, July $2020 \bullet$ Vol.13, No.3 
The study found problem solving skills as important skills to the students and relevant for integrating into the curriculum based on the respondents' opinion. However, problem solving skills was rated the least among the 8 (eight) identified skills. Though, the ranking of the skills was still within the assessment level that is considered as important for metalwork technology students. This findings concise with the report of Harris and Rogers (2008) who posited that problem solving skills is an essential skills that technology students required to be successful in school and workplace activities. Therefore, integrating problem solving skills into curriculum of metalwork technology could assist the students to develop the skills and make them to become a potential problem solver which is one of the essential attributes that are required by employers.

\section{CONCLUSION}

The study found that there is no curriculum specifically for the development of nontechnical skills among metalwork technology students. Thus, the need for the integration of the skills into the existing training program of metalwork technology in Nigeria technical colleges. Based on the review of literature, it was found that the integration of non-technical skills in the metalwork technology curriculum could improve the development of the skills of students, as prerequisite for employment. Therefore, if Nigeria as a nation is to bridge the gap of inadequate skills among the graduates, there is need for the Federal Government of Nigeria and National Board for Technical and Vocational Education as the policy makers to provide a policy structure for the integrating and development of non-technical skills in Nigeria technical colleges. The teachers should be exposed or trained adequately on the integrating approaches so as to play their roles in enhancing the non-technical skills of the students. It is recommended that industry play a substantial role in the development of non-technical skills. Consequently, there should be collaboration between the colleges and the industry to consolidate the fostering of non-technical skills among the students. Further study can be conducted in other Zones of Nigeria since the study is carried out in the southwestern part of Nigeria. The study only considered eight components, more components should be identified and use for the purpose of further study.

\section{REFERENCES}

Abas-Mastura, M., Imam, O. A., \& Osman, S. (2013). Employability skills and task performance of employees in government sector. International Journal of Humanities and Social Science, 3(4), 150-162.

Akinyemi, S., Ofem, I. B., \& Ikuenomore, S. (2012). Graduate turnout and graduate employment in Nigeria. International Journal of Humanities and Social Science, 2(14), 257-265.

Awang, Z. (2014). A handbook on SME: For Academicians and practitioners: MPWS Rich Resources.

Awang, Z. (2015). SEM made simple: a gentle approach to learning structural equation modeling: MPWS Rich Publication. 
Blom, A., \& Saeki, H. (2011). Employability and skill set of newly graduated engineers in India. Policy Research working paper; No. WPS 5640. Washington, DC: World Bank.

Buntat, Y. (2004). Integrasi kemahiran"employability"dalam program pendidikan vokasional pertanian dan industri di Malaysia (Unpublished doctoral dissertation). Universiti Teknologi Malaysia.

Buntat, Y., Jabor, M. K., Saud, M. S., Mansor, S. M. S. S., \& Mustaffa, N. H. (2013). Employability skills element's: Difference perspective between teaching staff and employers industrial in Malaysia. Procedia-Social and Behavioral Sciences, 93, 15311535 .

Chijioke, O. P., Wordu Chiduhiegem, C. R. (2016). Challenges of Unemployment among Technology Graduates of Polytechnic Education in Nigeria. Journal of Scientific and Engineering Research, 3(6), 405-409.

Chithra, R. (2013). Employability Skills-a study on the perception of the engineering students and their prospective employers. Global Journal of Management and Business Studies, 3(5), 525-534.

Deba, A. A., Jabor, M. K., Buntat, Y., \& Musta'mal, A. H. (2014). Potential of servicelearning on students' interpersonal skills development in technical and vocational education. Asian Social Science, 10(21), 1. doi:10.5539/ass.v10n21p1.

Dupin-Bryant, P. A. (2008). Computer-mediated collaborative projects: Processes for enhancing group development. Journal of Applied Research for Business Instruction, $6(2), 1$.

Hair, J. F., Ringle, C. M., \& Sarstedt, M. (2011). PLS-SEM: Indeed a silver bullet. Journal of Marketing theory and Practice, 19(2), 139-152.

Harris, K. S., \& Rogers, G. E. (2008). Soft kills in the technology education classroom: What do students need? Technology Teacher, 68(3), 19-24.

Heimler, R. (2010). Attitudes of college graduates, faculty, and human resource managers regarding the importance of skills acquired in college and needed for job performance and career advancement potential in the retail sector. Dowling College.

Holdsworth, T., \& Gearhart, E. (2002). Teaching and assessing employability skills. Modern Machine Shop, 74(12), 1-2.

ILO. (2017). ILO's world employment and social outlook trends 2017. WESO Publication.

Inti, M. M., Abdul Latib, A., \& Oke, J. O. (2015). Confirmatory Factor analysis of oral communication's learning outcomes for integrating generic employability skills into mechnical engineering curriculum in Niggeria politechnics. International Journal of Educational Foundation and Management, 9(2), 337-349. 
Kline, R. B. (2015). Principles and practice of structural equation modeling. Guilford publications.

Laguador, J. M., \& Dotong, C. I. (2013). Tracer study of BS computer engineering graduates of Lyceum of the Philippines University. International Journal of Management, IT and Engineering, 3(8), 387.

Leveson, L. (2000). Disparities in perceptions of generic skills: Academics and employers. Industry and Higher Education, 14(3), 157-164.

Lindsay, C. (2002). Long-term unemployment and the "employability gap": priorities for renewing Britain's New Deal. Journal of European Industrial Training, 26(9), 411419.

Norani, M. N. (2006 ). Kepentingan Kemahiran Generik untuk Pekerjaan di Industri dan Faktor Pembangunannya dalam Pendidikan Vokasional di Sekolah Menengah Teknik (Unpublished doctoral dissertation). Universiti Teknologi Malaysia, Skudai.

Oduwole, T. A. (2015). Youth unemployment and poverty in Nigeria. International Journal of Sociology and Anthropology Research, 1(2), 23-39.

Pitan Oluyomi, S., \& Adedeji, S. (2012). Skills Mismatch among university graduates in the Nigeria labor market. US-China Education Review, AI, 90-98.

Rasul, M. S., \& Mansor, A. N. (2013). Employability skills indicator as perceived by manufacturing employers. Asian Social Science, 9(8), 42.

Salami, C. (2013). Youth unemployment in Nigeria: A time for creative intervention. International Journal of Business and Marketing Management, 1(2), 18-26.

Shafie, L. A., \& Nayan, S. (2010). Employability awareness among Malaysian undergraduates. International Journal of Business and Management, 5(8), 119.

Tabachnick, B. G., Fidell, L. S., \& Ullman, J. B. (2007). Using multivariate statistics (Vol. 5). Boston, MA: Pearson.

Tabatabaei, M., \& Lam, M. (2013). Awareness and usage of collaborative and communication technology in Students' Teamwork. Journal of International Technology and Information Management, , 22(2), 71-83.

Teijeiro, M., Rungo, P., \& Freire, M. J. (2013). Graduate competencies and employability: The impact of matching firms' needs and personal attainments. Economics of Education Review, 34, 286-295.

Weston, R., \& Gore Jr, P. A. (2006). A brief guide to structural equation modeling. The counseling psychologist, 34(5), 719-751.

Yost, C. A., \& Tucker, M. L. (2000). Are effective teams more emotionally intelligent? Confirming the importance of effective communication in teams. Delta Pi Epsilon Journal, 42(2), 101. 